\title{
Effects of Dietary Threonine Levels on the Threonine-degrading Enzyme Activities and Tissue Threonine Related Amino Acid Concentration in Rats
}

\author{
Reiko WATANABE, Shinobu FUJIMURA*, \\ Motoni KADOW AKI* and Teru ISHIBASHI* \\ Niigata Women's College, Niigata-shi 950-0806 \\ *Faculty of Agriculture, Niigata University, Niigata-shi 950-2102
}

(Received September 12, 1997)

\begin{abstract}
In order to compare the responses of plasma amino acid (AA) concentrations of glycine (Gly) and serine (Ser) to the dietary excess threonine (Thr) in rats and chickens, adult male Wistar/ST rats weighing $304.5 \pm 5.2 \mathrm{~g}$ were fed diets with five graded levels of Thr from 0.32 to $0.67 \%$. The composition of experimental diets was similar to that of the basal diet used for laying hens. Tissue concentrations (TC) of three AA, Thr, Gly and Ser, expressed as $\mu \mathrm{mol} / \mathrm{g}$ tissue and the enzyme activities expressed as $\mu \mathrm{mol} / \mathrm{g}$ tissue $/ 30 \mathrm{~min}$ relating to conversion of Thr to Gly and interconversion of Gly and Ser in homogenates of liver, kidney and duodenum were determined. In the liver, when dietary Thr increased from 0.32 to $0.42 \%$. TC of Thr increased from 0.50 to 0.73 $\mu \mathrm{mol} / \mathrm{g}$, and then increased linearly with increasing dietary Thr levels. When dietary Thr levels were higher than $0.42 \%$, TC of Thr in the kidney and duodenum were higher 45 and $75 \%$ at $0.67 \%$ dietary Thr level compared to those at less than $0.42 \%$ dietary Thr level, respectively. TC of Gly in the three tissues remained constant regardless of dietary Thr levels, but those in the kidney were two times higher than those in other two tissues. TC of Ser in the liver tended to increase, however, those in the kidney and duodenum were not affected by dietary Thr levels. In the liver, Thr aldolase activity decreased slightly, and then increased at dietary Thr levels exceeded $0.42 \%$. However, all enzyme activities except Ser-hydroxymethyltransferase in the liver were not affected by dietary Thr levels. In contrast to the data of laying hens reported previously, the activity of liver Ser-hydroxymethyltransferase converting Ser to Gly decreased with increasing dietary Thr levels. These responses of enzyme activities in the rat liver might be one of the reasons for the difference in the responses of $\mathrm{TC}$ and plasma concentrations of Gly and Ser to the dietary excess $\mathrm{Thr}$ in rats and chickens.
\end{abstract}

Anim. Sci. Technol. (Jpn.) 69 (2) : 108-116,1998

Key words : Adult rats, Serine degradation, Threonine degradation, Threonine excess diet, Tissue amino acid concentration

When a threonine (Thr) excess diet was supplied, the plasma concentration (PC) of Thr increased, that of glycine (Gly) remained constant and that of serine (Ser) decreased in chicks $^{37}$ and laying hens ${ }^{10,19)}$. However, the responses of PC of Gly and Ser to changes of dietary $T$ hr levels in rats were unclear. For the degradation of Thr, Thr dehydratase ( $\mathrm{T}$ DHT, EC 4.2.1.16) catalyzing Thr to $\alpha-$ ketobutyric acid and Thr aldolase (T-AL, EC 4.1.2.5) catalyzing Thr to Gly in cytosole, and Thr dehydrogenase (T-DHG, EC 1.1.1.103) catalyzing $\mathrm{Thr}$ to 2 -aminoacetacetic acid in mitochondria, have been recognized as major 
enzymes in the mammalian liver ${ }^{7)}$.

In the previous paper ${ }^{21}$, it was reported that T-AL activities responded to changes of dietary Thr levels in laying hens. They remained constant at the range of deficient dietary $\mathrm{Thr}$ levels from 0.32 to $0.42 \%$, and then increased significantly with increasing dietary $\mathrm{Thr}$ levels in the duodenum. The similar tendencies were observed in the activities of $\mathrm{T}-\mathrm{AL}$ and Ser hydroxymethyltransferase (S-HMTF, EC 2.1.2.1) catalizing reversible interconversion of Gly and Ser, in the liver and kidney. However, S-HMTF activities from Gly to Ser was not affected by changes of dietary Thr levels, and resulted in the increment of conversion from Ser to Gly, which might be one of the reasons why the tissue Ser concentration decreased, when dietary Thr levels were higher than its requirement in chickens.

Therefore, the objective of this study was to compare the responses of PC of Gly and Ser to the dietary excess $\mathrm{Thr}$ in rats and chickens. The tissue amino acid (AA) concentration and Thr metabolic enzyme activities were investigated in rats fed the diets containing graded levels of Thr and similar AA composition to that for laying hens in the previous report ${ }^{21)}$.

\section{Materials and Methods}

\section{Animals}

Male Wistar/ST rats weighing 280 to $290 \mathrm{~g}$ at 9 weeks of age were purchased from a commercial farm (Japan SLC, Inc., Shizuoka), and housed in individual wire mesh cages in an environmentally controlled room $\left(22 \pm 2^{\circ} \mathrm{C}\right.$ and $12 \mathrm{~h}$ light from $07: 00$ to $19: 00$ ). They were fed an experimental diet containing Thr $(0.55 \%)$ for 5 days to adapt to the experimental diet. And then, rats with average body weight, $304.5 \pm 5.2 \mathrm{~g}$, were divided into five experimental dietary groups with 6 rats each, and given free access to the experimental diets and water for 7 days. Feed intake and body weight were recorded every day during the experimental period.

\section{Diets}

The basal diet consisted mainly of corn and wheat bran, and contained $2.92 \mathrm{kcal}(12.2 \mathrm{~kJ})$ $\mathrm{ME} / \mathrm{g}$ and $12.7 \%$ crude protein $(\mathrm{CP})$ as shown in Table 1. This dietary composition was the same as that of the basal diet used for laying hens in the previous report ${ }^{21)}$, except for $9.2 \%$ of calcium carbonate which was essential for eggshell formation in the layer diet was replaced by agar on an equal weight basis. Dietary AA concentrations were calculated from the analytical data of used feedstuffs except for methionine, cystine and tryptophan, and the concentrations of them were calculated from the table in NRC (1994) ${ }^{13)}$. To meet $100 \%$ of AA of NRC (1994) ${ }^{13)}$ requirements for laying hens, seven essential AA were supplemented. Five diets with graded levels of Thr from 0.32 to $0.67 \%$ were prepared by balancing the same amount of glutamic acid. The ratio of essential AA to non-essential AA in the added AA mixture was adjusted to be about $2: 1$. As shown in Table 2, dietary levels of all A A were higher than those for growth and reproduction of rats by NRC $(1978)^{12)}$. The difference of ME and $\mathrm{CP}$ caused by balancing Thr by glutamic acid was calculated to be maximumly $0.09 \mathrm{kcal}$ $\mathrm{ME} / \mathrm{g}$ and $0.05 \% \mathrm{CP}$ of the diet, respectively.

Table 1. Composition of basal diet

\begin{tabular}{lr} 
& (Unit :\%) \\
\hline \hline Corn grain & 34.4 \\
Corn gluten meal $(62.0 \% \mathrm{CP})$ & 3.5 \\
Wheat bran & 7.0 \\
Soybean oil & 1.0 \\
Choline chloride & 0.1 \\
Calcium phosphate tribasic & 1.2 \\
Sodium chloride & 0.3 \\
Vitamin mineral premix ${ }^{1)}$ & 0.3 \\
Amino acid mixture & 1.9 \\
Glutamic acid & 1.1 \\
Agar & 9.2 \\
\hline
\end{tabular}

1) See Yamamoto and Ishibashi ${ }^{19)}$.

2) See Table 2. 
WATANABE, FUJIMURA, KADOWAKI and ISHIBASHI

Table 2. Amino acid composition of amino acid mixture, experimental diet and NRC requirements for rats $(1978)^{12)}$

(Unit :\%)

\begin{tabular}{lccc}
\hline \multicolumn{1}{c}{ Amino acid } & Amino acid mixture & Experimental diet & NRC requirement \\
\cline { 2 - 4 } Threonine & 0 to 0.35 & 0.32 to 0.67 & 0.4 \\
Arginine & 0.29 & 0.70 & 0.3 \\
Histidine & - & 0.24 & 0.2 \\
Isoleucine & 0.31 & 0.65 & 0.4 \\
Leucine & - & 1.16 & 0.7 \\
Lysine & 0.42 & 0.69 & 0.4 \\
Methionine & 0.19 & 0.30 & 0.5 \\
Phenylalanine & 0.03 & 0.47 & 0.4 \\
Tryptophan & 0.06 & 0.15 & 0.1 \\
Valine & 0.25 & 0.70 & 0.5 \\
Glutamic acid & 1.10 to 0.75 & 1.55 to 1.20 & - \\
\hline
\end{tabular}

\section{Tissue preparation}

On the 7th day after changing to five graded experimental diets, rats were weighed and killed by decapitation after taking about $0.4 \mathrm{~m} l$ of blood samples from the Vena caudalis by vein puncture with heparinized syringes. The liver, kidney and duodenum were weighed, and quickly sliced in ice-cold $0.14 \mathrm{M} \mathrm{KCl}$ solution containing $0.25 \%$ Triton $\mathrm{X}-100$ at $4^{\circ} \mathrm{C}$. The tissues were homogenized with a polytron sonicator (Kinematica, Switzerland), and diluted with 5 volumes of ice-cold $0.14 \mathrm{M} \mathrm{KCl}$ solution. The tissue homogenates were immediately used for assay as described as follows.

\section{Tissue free AA concentration}

A portion of tissue homogenates was deproteinized immediately by addition of 5 fold amount of $3.0 \%$ sulfosalicylic acid, and the mixture was stood for at least $30 \mathrm{~min}$ at $4^{\circ} \mathrm{C}$. The precipitated fraction was removed by centrifugation at $1,800 \times \mathrm{g}$ for $15 \mathrm{~min}$, and the supernatant was stored at $-25^{\circ} \mathrm{C}$ until analysis of AA. Approximately $10 \mu l$ of samples were applied to a high performance liquid chromatograph (Shimadzu, LC-10A, Kyoto) equipped with a Shimadzu lithium type ion exchange column at $39^{\circ} \mathrm{C}$ for the determination of AA according to Fujimura et al..$^{5}$.

\section{Enzyme assay of Thr, Gly and Ser conver- sion}

The assay system reported by Davis and Austic $^{2)}$ was modified. The concentrations of each substrate, Thr, Gly or Ser, and each tissue homogenate, $\mathrm{pH}$ and reaction time were determined in the same conditions as reported in the previous report used laying hens ${ }^{21)}$. The reaction mixture of $1.0 \mathrm{ml}$ of $0.1 \mathrm{M}$ phosphate buffer solution ( $\mathrm{pH} 7.5)$ and $1.0 \mathrm{ml}$ of homogenate was preincubated for $3 \mathrm{~min}$ at $37^{\circ} \mathrm{C}$, and then $1.0 \mathrm{ml}$ of each substrate in $0.1 \mathrm{M}$ phosphate buffer solution was added. The final concentrations of substrates were $1.0 \mu \mathrm{mol} / \mathrm{ml}$ for all tissue homogenates. After $30 \mathrm{~min}$, the reaction was stopped by addition of $1.0 \mathrm{~m} l$ of $9.0 \%$ sulfosalicylic acid solution, and the mixture was stood for at least $30 \mathrm{~min}$ at $4^{\circ} \mathrm{C}$. The precipitated fractions were separated by centrifugation, and the supernatants were stored at $-25^{\circ} \mathrm{C}$ until analysis. Amino acid analyses were performed in the same manner as above mentioned. Enzyme activities were expressed as $\mu \mathrm{mol}$ of Gly or Ser formed per 30 min per gram tissue.

\section{Statistical analysis}

Statistical significance was estimated by analysis of variance and Duncan's new multiple range test using the General Linear Model 
procedure in SAS ${ }^{\circledR 17)}$. Statements of significance were based on $\mathrm{P}<0.05$ unless otherwise stated.

\section{Results}

\section{Body and tissue weights, and feed intake}

Table 3 shows the average feed intake, body weight change, and weights of liver, kidney and duodenum of rats fed the diets containing graded levels of $\mathrm{Thr}$. The feed intake ranged from 22.2 to $23.4 \mathrm{~g}$, but no differences were found among them. Body weight changes and tissue weights expressed as grams and percentages of body weight were not affected by changes of dietary Thr levels.

\section{Tissue AA concentrations}

When the dietary Thr increased, PC of Thr increased from 53.2 to $450.6 \mathrm{nmol} / \mathrm{m} l$ and that of Ser from 101.0 to $149.7 \mathrm{nmol} / \mathrm{ml}$, but that of Gly remained constant (Fig. 1). Tissue concentrations (TC) of AA of rats fed the diets with graded levels of Thr are shown in Table 4. Tissue concentrations of Gly and Ser in the liver, kidney and duodenum did not respond to changes of dietary Thr levels. Tissue concentrations of Thr in all tissues remained constant below $0.42 \%$ dietary Thr levels, and then increased linearly with increasing dietary $\mathrm{Thr}$ levels. Tissue concentrations of Thr, Gly and Ser in the kidney were higher than those in the duodenum, and the latter were higher than those in the liver. Especially, TC of Gly in the kidney (7.14 to 7.40 ) were higher than those in the duodenum (2.76 to 3.18 ) and liver (2.54 to $3.09 \mu \mathrm{mol} / \mathrm{g}$ tissue). These differences were not narrowed by recalculating as $\mu \mathrm{mol} / \mathrm{m} l$ of water in tissue.

\section{Enzyme activities}

Enzyme activities expressed as $\mu \mathrm{mol}$ of products per gram tissue per $30 \mathrm{~min}$ in the liver, kidney and duodenum are summarized in Table 5. The response of enzymes to changes of dietary Thr levels were different among tissues. All enzyme activities in the kidney

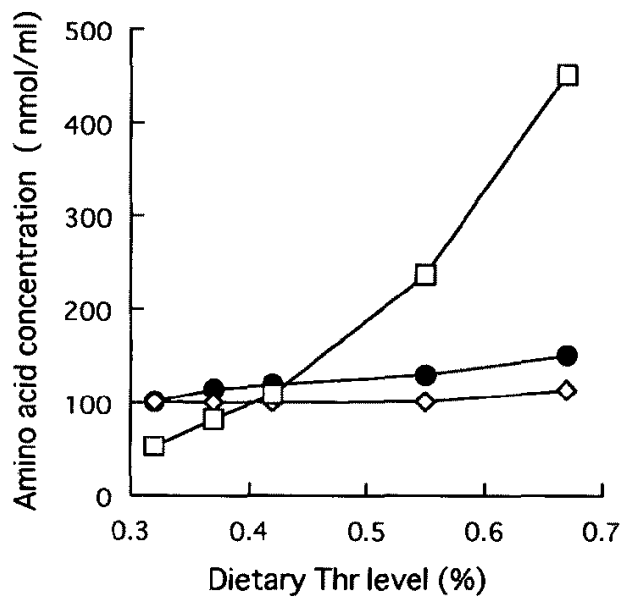

Fig. 1. Plasma concentrations of threonine, glycine and serine of adult rats fed diets with five graded levels of threonine for 7 days.

Each value is means for 6 rats. $\square$; Thr, $\diamond$; Gly, ; Ser.

Table 3. Feed intake, body weight change and tissue weight of adult rats fed diets with five graded levels of threonine for 7 days

\begin{tabular}{lllllll}
\hline \multicolumn{1}{c}{ Dietary threonine (\%) } & \multicolumn{1}{c}{0.32} & 0.37 & 0.42 & 0.55 & 0.67 & $\begin{array}{c}\text { Pooled } \\
\mathrm{SE}\end{array}$ \\
\hline Feed intake (g/rat/day) & 22.2 & 23.4 & 22.7 & 22.3 & 22.5 & 0.6 \\
Body weight change (g/day) & 3.45 & 3.37 & 3.64 & 3.48 & 3.52 & 0.17 \\
Weight of tissues (g) & & & & & & \\
$\quad$ Liver & $10.3(3.1)$ & $10.1(3.0)$ & $10.0(3.1)$ & $10.0(3.1)$ & $10.0(3.0)$ & 0.3 \\
$\quad$ Kidney & $1.86(0.55)$ & $1.81(0.53)$ & $1.82(0.53)$ & $1.93(0.56)$ & $1.82(0.54)$ & 0.04 \\
$\quad$ Duodenum & $0.79(0.20)$ & $0.79(0.20)$ & $0.87(0.22)$ & $0.81(0.21)$ & $0.83(0.21)$ & 0.03 \\
\hline
\end{tabular}

Values are means for 6 rats.

Values in parentheses are percentage to body weight. 
Table 4. Concentrations of threonine, glycine and serine in liver, kidney and duodenum of adult rats fed diets with five graded levels of threonine for 7 days

(Unit : $\mu \mathrm{mol} / \mathrm{g}$ tissue)

\begin{tabular}{|c|c|c|c|c|c|c|c|}
\hline \multirow{2}{*}{ Tissue } & \multirow{2}{*}{$\begin{array}{c}\text { Amino } \\
\text { acid }\end{array}$} & \multicolumn{5}{|c|}{ Dietary threonine (\%) } & \multirow{2}{*}{$\begin{array}{l}\text { Pooled } \\
\text { SE }\end{array}$} \\
\hline & & 0.32 & 0.37 & 0.42 & 0.55 & 0.67 & \\
\hline \multirow{6}{*}{ Liver } & Thr & $0.50^{c}$ & $0.64^{c}$ & $0.73^{c}$ & $1.06^{b}$ & 1. $44^{\mathrm{a}}$ & 0.04 \\
\hline & & $\left(0.50^{c}\right)$ & $\left(0.63^{c}\right)$ & $\left(0.60^{c}\right)$ & $\left(1.06^{b}\right)$ & $\left(1.33^{a}\right)$ & \\
\hline & Gly & 2.54 & 2.90 & 2.81 & 2.69 & 3.09 & 0.10 \\
\hline & & $(2.51)$ & $(2.61)$ & (2. 34) & $(2.42)$ & $(2.36)$ & \\
\hline & Ser & 1.11 & 1.14 & 1. 21 & 1. 22 & 1.31 & 0.07 \\
\hline & & $\left(5.49^{\mathrm{a}}\right)$ & $\left(5.24^{\mathrm{a}}\right)$ & $\left(5.55^{a}\right)$ & $\left(4.56^{\mathrm{b}}\right)$ & $\left(4.08^{c}\right)$ & \\
\hline \multirow{6}{*}{ Kidney } & Thr & 1. $41^{\mathrm{c}}$ & 1. $40^{c}$ & 1. $46^{\mathrm{c}}$ & $1.84^{\mathrm{b}}$ & $2.02^{\mathrm{a}}$ & 0.06 \\
\hline & & $\left(0.50^{c}\right)$ & $\left(0.55^{\circ}\right)$ & $\left(0.54^{c}\right)$ & $\left(0.94^{\mathrm{b}}\right)$ & (1. $\left.45^{\mathrm{a}}\right)$ & \\
\hline & Gly & 7. 25 & 7.14 & 7.23 & 7. 40 & 7.20 & 0.12 \\
\hline & & $(7.07)$ & $(7.64)$ & $(7.48)$ & $(7.57)$ & $(7.60)$ & \\
\hline & Ser & 3.13 & 2. 89 & 2,88 & 2. 81 & 2. 84 & 0.09 \\
\hline & & $\left(3.91^{\mathrm{a}}\right)$ & $\left(3.94^{a}\right)$ & $\left(4.02^{\mathrm{a}}\right)$ & $\left(3.56^{\mathrm{ab}}\right)$ & $\left(3.02^{b}\right)$ & \\
\hline \multirow{6}{*}{ Duodenum } & Thr & 1. $11^{\mathrm{c}}$ & 1. $18^{c}$ & 1. $11^{c}$ & 1. $62^{\mathrm{b}}$ & $1.95^{a}$ & 0.07 \\
\hline & & $\left(0.90^{b}\right)$ & $\left(1.02^{b}\right)$ & $\left(1.01^{b}\right)$ & $\left(1.32^{\mathrm{ab}}\right)$ & $\left(1.71^{a}\right)$ & \\
\hline & Gly & 2. 98 & 2. 94 & 2.76 & 2.93 & 3. 18 & 0.13 \\
\hline & & (4. 48) & $(4.67)$ & $(5.00)$ & $(5.00)$ & $(5,09)$ & \\
\hline & Ser & 2.23 & 2.39 & 2. 14 & 2. 25 & 2.34 & 0.11 \\
\hline & & $\left(3.31^{\mathrm{ab}}\right)$ & $\left(3.53^{\mathrm{ab}}\right)$ & $\left(3.88^{\mathrm{a}}\right)$ & $\left(3.35^{\mathrm{ab}}\right)$ & $\left(2.96^{b}\right)$ & \\
\hline
\end{tabular}

Values are means for 6 rats.

Values in parentheses are means for 6 laying hens in the previous report ${ }^{21}$.

${ }^{a-c}$ Means in the same row with different superscripts differ significantly $(\mathrm{P}<0.05)$.

tended to increase at the dietary Thr levels from 0.32 to 0.37 or $0.42 \%$ and then decrease with increasing dietary Thr levels. Adversely those in the duodenum tended to decrease in the dietary Thr levels from 0.32 to $0.42 \%$, and then increase with increasing dietary $\mathrm{Thr}$ levels, but the differences observed were not significant. In the liver, the enzyme activities converting Thr to Ser, and Gly to Ser remained constant, but those converting Thr to Gly decreased at the dietary $\mathrm{Thr}$ levels from 0.32 to $0.42 \%$, and then increased with increasing dietary Thr levels as those in the kidney. Those converting Ser to Gly decreased linearly from 1.98 at $0.32 \%$ dietary $\mathrm{Thr}$ level to $1.32 \mu \mathrm{mol} / \mathrm{g}$ tissue $/ 30 \mathrm{~min}$ at $0.67 \%$ dietary $\mathrm{Thr}$ level.

\section{Discussion}

Although the body weight gain in laying hens increased curvilinearly with increasing dietary Thr levels ${ }^{21)}$, there were no differences in those of rats among the five graded $\mathrm{Thr}$ groups (Table 3). Accordingly, no differences of tissue weights were observed in rats fed the diets with different Thr levels. These results indicated that these parameters were unavailable for estimation of $\mathrm{Thr}$ requirements of adult rats.

Threonine requirements of growing rats have been reported to be $0.42 \%$ from data of $\mathrm{PC}$ of $\mathrm{Thr}^{11)}, 0.43 \%$ from data of growth assay and protein efficiency ratio ${ }^{15}$, and $0.50 \%$ from data of growth assay ${ }^{9)}$. However, recently, there are no reports on the determination of $\mathrm{Thr}$ 
Table 5. Glycine and serine formed from three substrates, threonine, glycine and serine in liver, kidney and duodenum of adult rats fed diets with five graded levels of threonine for 7 days

(Unit : $\mu \mathrm{mol} / \mathrm{g}$ tissue $/ 30 \mathrm{~min}$ )

\begin{tabular}{|c|c|c|c|c|c|c|c|c|}
\hline \multirow{2}{*}{ Tissue } & \multirow{2}{*}{ Substrare } & \multirow{2}{*}{ Product } & \multicolumn{5}{|c|}{ Dietary threonine $(\%)$} & \multirow{2}{*}{$\begin{array}{l}\text { Pooled } \\
\text { SE }\end{array}$} \\
\hline & & & 0.32 & 0.37 & 0.42 & 0.55 & 0.67 & \\
\hline \multirow{8}{*}{ Liver } & \multirow[t]{2}{*}{ Thr } & \multirow[t]{2}{*}{ Gly } & $1.61^{3}$ & 1. $44^{\mathrm{ab}}$ & $1.27^{\mathrm{b}}$ & 1. $37^{\mathrm{ab}}$ & $1.60^{\mathrm{a}}$ & \multirow[t]{2}{*}{0.06} \\
\hline & & & $(1.56)$ & $(1.51)$ & $(1.43)$ & $(1.42)$ & (1.55) & \\
\hline & \multirow[t]{2}{*}{ Thr } & \multirow[t]{2}{*}{ Ser } & 0.80 & 0.88 & 0.79 & 0.74 & 0.83 & \multirow[t]{2}{*}{0.04} \\
\hline & & & (1. 12) & $(1 . \infty 0)$ & $(0.99)$ & $(1.12)$ & $(1.05)$ & \\
\hline & \multirow[t]{2}{*}{ Gly } & \multirow{2}{*}{ Ser } & 0.97 & 0.97 & 0.90 & 0.85 & 0.96 & \multirow[t]{2}{*}{0.04} \\
\hline & & & $(1.01)$ & $(1.12)$ & $(1.08)$ & $(1.04)$ & (1.11) & \\
\hline & \multirow[t]{2}{*}{ Ser } & \multirow[t]{2}{*}{ Gly } & $1.98^{\mathrm{a}}$ & 1. $85^{\mathrm{a}}$ & 1. $49^{\mathrm{ab}}$ & 1. $35^{\mathrm{b}}$ & 1. $32^{\mathrm{b}}$ & \multirow[t]{2}{*}{0.07} \\
\hline & & & $(1.50)$ & (1.52) & $(1.48)$ & (1.65) & $(1.76)$ & \\
\hline \multirow{8}{*}{ Kidney } & \multirow[t]{2}{*}{ Thr } & \multirow[t]{2}{*}{ Gly } & 3.25 & 3.67 & 3.74 & 3.55 & 3.09 & \multirow[t]{2}{*}{0.12} \\
\hline & & & $\left(0.96^{b}\right)$ & $\left(0.86^{\mathrm{b}}\right)$ & $\left(0.76^{b}\right)$ & $\left(1.20^{a}\right)$ & $\left(1.38^{a}\right)$ & \\
\hline & \multirow[t]{2}{*}{ Thr } & \multirow[t]{2}{*}{ Ser } & 3.14 & 3.36 & 3. 40 & 3.43 & 2.96 & \multirow[t]{2}{*}{0.14} \\
\hline & & & $(1.39)$ & $(1.40)$ & (1. 37) & $(1.46)$ & $(1.50)$ & \\
\hline & \multirow[t]{2}{*}{ Gly } & \multirow[t]{2}{*}{ Ser } & 3. 40 & 3. 57 & 3. 30 & 3. 17 & 2.80 & \multirow[t]{2}{*}{0.12} \\
\hline & & & $(1.41)$ & (1. 36) & $(1.41)$ & $(1.40)$ & (1. 43) & \\
\hline & \multirow[t]{2}{*}{ Ser } & \multirow[t]{2}{*}{ Gly } & 3.27 & 3.90 & 3.66 & 3.59 & 3.52 & \multirow[t]{2}{*}{0.15} \\
\hline & & & $(1.26)$ & $(0.93)$ & $(0.86)$ & $(1.10)$ & $(1.26)$ & \\
\hline \multirow{8}{*}{ Duodenum } & Thr & Gly & 7.00 & 6. 36 & 5. 70 & 6.10 & 6.85 & 0.31 \\
\hline & & & $\left(3.49^{\mathrm{b}}\right)$ & $\left(3.58^{\mathrm{b}}\right)$ & $\left(3.59^{b}\right)$ & $\left(4.56^{a}\right)$ & $\left(4.96^{\mathrm{a}}\right)$ & \\
\hline & Thr & Ser & 7.11 & 6.43 & 5.13 & 5.95 & 6.92 & 0.28 \\
\hline & & & $\left(2.61^{b}\right)$ & $\left(2.57^{b}\right)$ & $\left(2.89^{b}\right)$ & $\left(3.28^{a b}\right)$ & $\left(3.74^{\mathrm{a}}\right)$ & \\
\hline & Gly & Ser & 6.97 & 6. 79 & 5. 08 & 5.76 & 6.93 & 0.22 \\
\hline & & & (2.83) & $(2.90)$ & $(2.38)$ & $(2.97)$ & $(3.24)$ & \\
\hline & Ser & Gly & 6.81 & 6.31 & 6.00 & 6.15 & 6.44 & 0.30 \\
\hline & & & $\left(3.29^{b}\right)$ & (3. $\left.79^{\mathrm{ab}}\right)$ & (3. $\left.29^{b}\right)$ & $\left(4.31^{a}\right)$ & $\left(4.54^{\mathrm{a}}\right)$ & \\
\hline
\end{tabular}

Values are means for 6 rats.

Values in parentheses are means for 6 laying hens in the previous report ${ }^{21}$.

${ }^{\text {ab }}$ Means in the same row with different superscripts differ significantly $(\mathrm{P}<0.05)$.

requirement for adult rats, although Thr requirement for maintenance of rats by NRC (1978) was $0.18 \%{ }^{12)}$. Therefore, the dietary Thr levels used in this study might range from deficiency to excess from the above cited reports $^{9,11,12,15)}$. In laying hens, the Thr requirements determined from data of performance agreed well with those determined from data of plasma Thr concentration, and the latter agreed well with those determined from data of TC of Thr ${ }^{21}$. From the data of TC of liver, kidney and duodenum of young adult rats, the break points were estimated to be 0.42 ,
0.41 and $0.42 \%$, respectively (Fig. 2).

In Tables 4 and 5 , the values obtained in laying hens are presented in parentheses. There were no species differences in TC of Thr and Gly in the liver, those of Gly in the kidney, and those of Thr in the duodenum. However, $\mathrm{TC}$ of $\mathrm{Thr}$ in the kidney were higher in rats, and TC of Gly in the duodenum were higher in laying hens, and TC of Ser of rats were lower than those of laying hens in all tissues. These species differences might be caused by the difference of metabolic pathway for Thr degradation responding to dietary excess $\mathrm{Thr}$. The 


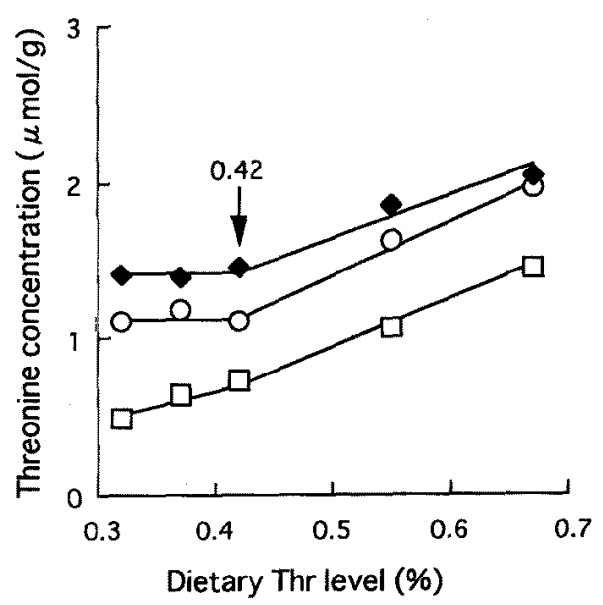

Fig. 2. Break points estimated from threonine concentrations in liver, kidney and duodenum of adult rats fed diets with five graded levels of threonine for 7 days.

Each value is means for 6 rats. $\square$; liver, ; kidney, $\mathrm{O}$; duodenum.

constancy of TC of Gly in tissues might be related in a way that the metabolic aspect of Gly is particularly complex involving conversion to Ser or other AA and synthesis of molecules such as purines and creatine, although its structure is the simplest one among naturally occuring $\mathrm{AA}^{8}$.

The reported Thr metabolism is summarized as follows. The conversion of $\mathrm{Thr}$ by $\mathrm{T}-\mathrm{AL}$. ( $\mathrm{Thr}$ to Gly) is recognized to be the most important in the Thr catabolism in mammals, but the major pathway for the degradation of $T h r$ is due to the action of T-DHT (Thr to $\alpha$ ketobutyric acid) in the rat liver, and can be induced by a high protein diet $t^{4,6,9,14}$ ) $T-A L$ should not be a genuine enzyme in the liver, and the apparent enzyme activity may result from a combined effect of T-DHT and lactate dehydrogenase (or oxo acid-linked NADPH dehydrogenase) in the liver cytosolic extract ${ }^{201}$. T-AL and S-HMTF, T-DHT and Serdehydratase (S-DHT, EC 4.2.1.3), appear to be a single protein, respectively ${ }^{17,18)}$. T-AL activity varies independently from $\mathrm{T}-\mathrm{DHT}$ activity ${ }^{1)}$. There are various studies for Thrdegrading enzymes and the relating enzymes as S-HMTF and S-DHT of the rat liver. Kang -Lee and Harper ${ }^{9)}$ determined S-DHT activity with Ser as a substrate in the liver of rat fed dietary Thr levels from 0.15 to $0.85 \%$, and showed that S-DHT activity tended to decrease with increasing dietary $\mathrm{Thr}$ levels. There results agreed with those in the present study.

The enzyme activities in the kidney and duodenum of rats were far higher than those of laying hens. The responses of four enzyme activities in the duodenum and three enzyme activities in the liver agreed well with each other. However, the activities of all enzymes in the kidney differed. The enzyme activities in rats increased and then decreased, while those of laying hens decreased and then increased. In the liver, the activity of S-HMTF converting Ser to Gly decreased in rats, but increased in laying hens. Although the significance of the species differences was unclear, the difference in S-HMTF activities between rats and laying hens might be one of the reasons why $\mathrm{PC}$ of Ser of laying hens decreased and that of rats increased when the dietary $\mathrm{Thr}$ was higher than the requirement.

\section{References}

1) Bird MI, Nunn PB. Metabolic homeostasis of Lthreonine in the normally-fed rat: Importance of liver threonine dehydrogenase activity. Biochem. J., 214 : 687-694. 1983.

2) Davis AT, Austic RE. Threonine-degrading enzymes in the chicken. Poult. Sci., $61: 2107^{-}$ 2111. 1982.

3) D'Mello JPF. Aspects of threonine and glycine metabolism in the chick (Gallus domesticus). Nutr. Metab., 15 : 357-363. 1973.

4) Freedland RA, Avery EH. Studies on threonine and serine dehydrase. J. Biol. Chem., 239 : 33573360. 1964.

5) Fujimura $S$, Yamamoto A, Kobayashi K, Ishibashi $T$. Comparison of performance of amino acid analysis with high performance liquid chromatograph equipped with sodiumand lithium-type column. Bull. Fac. Agric. 


\section{Threonine Metabolism in Rats}

Niigata Univ., $46: 71-77.1994$.

6) Goldstein L, Knox WE, Behrman EJ. Studies on the nature, inducibility, and assay of the threonine and serine dehydratase activities of rat liver. J. Biol. Chem., 237 : 2855-2860. 1962.

7) Hetenyi GJR, Anderson PJ, Kinson GA. Gluconeogenesis from threonine in normal and diabetic rats. Biochem. J., $224: 355-360$. 1984.

8) Jackson AA. The glycine story. Eur. J. Clin. Nutr., $45: 59$ 65. 1991.

9) Kang-Lee YA, Harper AE. Threonine metabolism in vivo: effect of threonine intake and prior induction of threonine dehydratase in rats. J. Nutr., $108:$ 163-175. 1978.

10) Kokawa $K$, Yamamoto $A$, Kadowaki $M$, Ishibashi $T$. Usefulness of plasma concentration for determination of threonine requirement within a short period in laying hens. Proc. 8th AAAP Anim. Sci. Cong., II : 780-781. 1996.

11) McLaughan JM, Illman WI. Use of free plasma amino acid requirements of the growing rat. $J$. Nutr., $93:$ 21-24. 1967.

12) National Research Council. Nutrient Requirements of Laboratory Animals. 3rd rev. ed. National Academy of Sciences. Washington, DC. 1978.

13) National Research Council. Nutrient Requirements of Poultry. 9th rev. ed. National Academy Press. Washington, DC. 1994.
14) Peraino C. Regulatory effects of glucocorticoides on ornithine aminotransferase and serine dehydratase in rat liver. Biochim. Biophys. Acta, 165 : 108-112. 1968.

15) Pick RI, Meade RJ. Amino acid supplementation of opaque-2 corn diets for growing rats. J. Nutr., $101:$ 1241-1248. 1971.

16) SAS Institute. SAS User's Guide : Statistics. Version 5 ed. SAS Inst. Inc., Cary, NC. 1985.

17) Schirch LV, Gross T. Serine transhydroxymethylase identification as the threonine and allothreonine aldolases. J. Biol. Chem., 243 : 5651-5655. 1968.

18) Selim AS, Greenberg DM. Futher studies on cystathione synthetase-serine deaminase of rat liver. Biochem. Biophys. Acta, $42: 211-217$. 1960.

19) Yamamoto A, Ishibashi T. Quick response of plasma amino acid concentration to dietary excess amino acids in laying hens. Anim. Sci. Technol. (Jpn.), $67:$ 1050-1057. 1996.

20) Yeung YG. L-Threonine aldolase is not a genuine enzyme in rat liver. Biochem. J., $237: 187-$ 190. 1986.

21) Watanabe R, lizuka $T$, Kokawa $K$, Yamamoto A, Ishibashi $T$. Effects of dietary threonine levels on the tissue amino acid concentration and threonine metabolic enzyme activity in laying hens. Anim. Sci. Technol. (Jpn.), 68 : 529-536. 1997. 


\title{
ラットのトレオニン分解酵素活性とトレオニン関連の遊離アミノ酸 濃度に対する飼料中のトレオニン含量の影響
}

\author{
渡邊令子・藤村 忍* ・門脇基二*・石橋 晃 ${ }^{*}$ \\ 県立新潟女子短期大学, 新渴市 950-0806 \\ * 新潟大学農学部、新潟市 950-2102
}

\begin{abstract}
トレオニン（Thr）を過剩に添加した䝭料を給与したときに，ラットの血墏中の遊離グリシン（Gly），

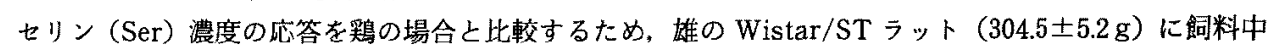
Thr 濃度が $0.32 \sim 0.67 \%$ までの 5 種類の試験飼料を給与した。試験飼料の組成は産卵㲕の場合の基礎飼

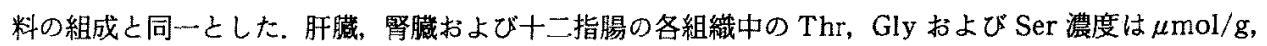
また, Thr から Gly への転換, および Gly と Ser の相互転換に関係する酵素活性は, 各組織 $1 \mathrm{~g}$ 当たり 30 分間の反応で生成される各アミノ酸の $\mu \mathrm{mol} / \mathrm{g}$ として測定した．䀒葴の $\mathrm{Thr}$ 浱度は，飼料中 $\mathrm{Thr}$ が 0.32 0.42\%までは徐々に增加し，その後飼料中 Thr 濃度が高くなるに従って直線的に增加した．留臟 と十二指腸の $\mathrm{Thr}$ 浱度む志た飼料中 $\mathrm{Thr}$ 濃度が $0.67 \%$ のき，0.42\% 以下のときに比較し各々 45 , $75 \%$ 增加した. 3 組織中 Gly 濃度は, 飼料中 Thr 濃度に関わらず一定であったが, 腎葴中 Gly 濃度は他 の 2 組織の Gly 濃度に比べ 2 倍以上高かった. 肝埇中 Ser 濃度は, 飼料中 Thr 濃度の増加に対応して わずかに増加する傾向がみられたが，腎臟や十二指腸の Ser 濃度は飼料中 Thr 濃度に影響されなかっ

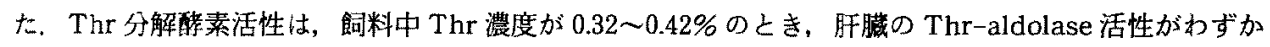
に減少し，その後，飼料中Thr浱度が高くなるに従って增加した。䀒臟のSer hydroxymethyltransferase 以外の他の醉菜活性は眗料中 Thr 濃度に影響されなかった。肝葴の Ser を Glyに転換する Ser-hydroxymethyltransferaseだけか， 産卵鷄の場合之は逆に飼料中の Thr 濃度 が高くなるに従って減少した，ラットの肝䐦におけるこのような代謝調節は，Thr 過剩飼料に対する ラットとニワトりとの組織, および血棌中 Ser 濃度の応答の差の理由の一因であることが示唆された。
\end{abstract}

日畜会報, 69 (2) : 108-116, 1998 